\title{
Pandemic Covid-19: Impact to Malay Language Learning among the Students in Public Universities
}

\author{
Shamsudin Othman (Corresponding author) \\ Department of Language and Humanities Education, Faculty of Educational Studies \\ Universiti Putra Malaysia, 43400 UPM Serdang, Selangor
}

Rosmaria Omar

Department of Foundation Studies, Faculty of Educational Studies

Universiti Putra Malaysia, 43400 UPM Serdang, Selangor

\begin{abstract}
Azhar Md Sabil
Department of Language and Humanities Education, Faculty of Educational Studies

Universiti Putra Malaysia, 43400 UPM Serdang, Selangor
\end{abstract}

Received: Oct. 8, $2021 \quad$ Accepted: Nov. 15, $2021 \quad$ Online published: Nov. 25, 2021

doi:10.5296/ijhrs.v11i4S.19249 URL: https://doi.org/10.5296/ijhrs.v11i4S.19249

\begin{abstract}
During the COVID-19 pandemic, social education moved from face to face to online learning to discourage large gatherings and crowds from catching the spread of the virus. This state of urgency involved all the students including university students. This paper aims to study the impacts of Pandemic Covid19 and identified the relationships between online learning, learning at home and self-management towards Malay Language learning among the students in public universities during MCO and 2) to develop a predictive model in the relationships between online learning, learning at home and self-management towards Malay Language learning among the students in public universities during MCO. Four variables which are online learning, learning at home, self-management, and Malay Language learning were analyzed using SPSS and AMOS. About 279 students from public universities were involved as respondents. Descriptive analysis, Correlation Pearson analysis and structural equation modeling (SEM) were used to answer the research objectives. An analysis of correlation Pearson showed that there are significant values derived from the relationship between online
\end{abstract}


learning and Malay language learning $(\mathrm{r}=.578, \mathrm{p}=.000)$. There is also a significant relationship between self-management and Malay language learning $(r=.368, p=.000)$. However, there is no relationship between learning at home and Malay Language learning $(\mathrm{r}=.026, \mathrm{p}=.294)$. The predictive model achieved good fit values of RMSEA=.061, IFI=.937, $\mathrm{CFI}=.936, \mathrm{TLI}=.925$ and $\mathrm{Chisq} / \mathrm{df}=2.001$. The implementation of online learning as a new norm and platform in teaching and learning Malay Language among the students gave a positive impact in terms of technology usage. However, there are needs for improvement to be considered in providing a more useful platform to change from face to face in conventional ways similarly to advanced technology. Meanwhile, the predictive model can serve as a source of reference in evaluating Malay language learning by using technology and other indicators for the future, for the sake of student's achievement.

Keywords: covid-19, online learning, self-management, learning at home, malay language learning

\section{Introduction}

The world is in shock, as the World Health Organization (WHO) declared a pandemic to Covid-19 on 11 March 2020. For Malaysia, our government implemented the Movement Control Order (MCO) on $18^{\text {th }}-31^{\text {st }}$ March 2020. This means that there were no meetings, universities and most businesses closed, with the exception of businesses involving food, health, security, telecom, finance, fuel and transportation. Even so, the MCO was eventually extended to 14 April 2020 due to rise in positive cases to 1,796 and 19 deaths on $25^{\text {th }}$ March. To date which is $17^{\text {th }}$ October 2020, there are 180 deaths reported, with 19, 627 total cases for Malaysia (National CPRC, MOH, 2020).

Initially, the schools and universities in Malaysia were closed for a week from $14^{\text {th }}$ to $22^{\text {nd }}$ March 2020. However, in conjunction with the MCO, the closing of universities was initially prolonged to $31^{\text {st }}$ March 2020 and to $14^{\text {th }}$ April 2020 after the second phase of the MCO. However, the Ministry of Education (MOE) made a quick decision to adjourn all school and extracurricular activities in March 2020 (MOE Malaysia, 2020a). When the number of cases had decreased and patients successfully recovered in July 2020, a new norm of life was introduced.

The Covid-19 pandemic has influenced students in many ways, particularly in classroom practice. This situation really affects those students in universities especially among the Malay Language students. Those students need to prepare themselves for "drama setting" as they are in the fifth semester of the course. In a normal learning setting, they would expectedly be sitting together, doing face to face learning with lecturers in order to get prepared for "drama staging" as a requirement for them to graduate. This is difficult, considering that at the time of writing, there is no instruction from the university to hold the study semester, but students need to learn online as an alternative way of learning to make sure that their progress in the semester will be going smoothly. Nobody, let alone no system has been prepared for that kind of health crisis as well as for its impact on the higher education system. Since online learning is convenient and made accessible to many students, it is still compulsory for students to attend face-to-face contacts. Students need to learn the 


\section{Macrothink}

International Journal of Human Resource Studies

ISSN 2162-3058 2021, Vol. 11, No. 4S

"Studying from Home" techniques using interactive tools like technology.

According to Walberg's Academic Achievement Theory (1984) achievement for a student is influenced by nine factors namely efficiency, level of development, motivation, quality of learning, quality in teaching, parental involvement, social class groups, peer groups and use of time outside the classroom (Walberg, 1985). These factors play an important role in producing the different ways of improving a student's achievement. These aspects are able to measure students' cognitive and affective abilities, level of motivation, quality of teaching, classroom's psychological climate as well as learning environment at home.

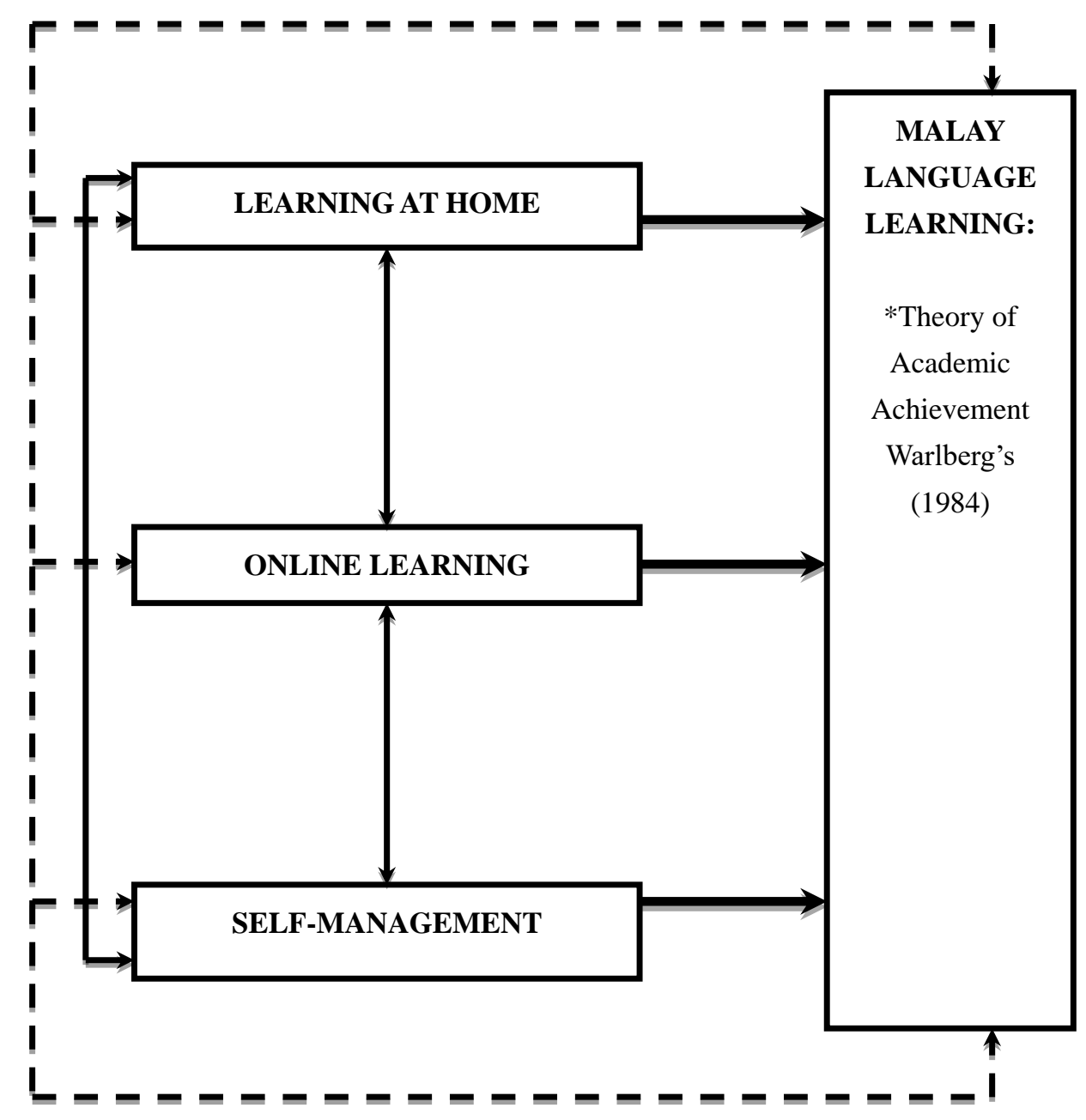

Figure 1. Conceptual Framework

Therefore, this theory is aligned with the conceptual framework, whereby once the Malay language students were at home, the learning environment was totally different from the university setting itself. They need to manage themselves so that they can fulfil their responsibilities as students and as children to their parents at home. Ofcourse they need to fulfill all the responsibilities and as students they also have to manage themselves to use online learning as a new platform to communicate and to learn.

The original model of Walberg's Theory of Academic Achievement (1984) includes the 
assessed curriculum, students 'aptitude, learning environment and student learning outcomes. This model shows that the learning environment acts as an independent variable and the learning outcome as a dependent variable. As an independent variable, the learning environment is a reflection of student learning outcomes including the cognitive and affective aspects, and at the same time, the learning environment as a dependent variable is influenced by factors such as curriculum teaching methods and different psychological interventions. In the context of this study, the dependent variable, Malay Language learning, is a benchmark for student achievement that is influenced by three factors, namely the independent variable, namely online learning, learning at home and self-management.

Therefore, this article aims to identify two objectives and measure three hypotheses as stated below:

1) To identify the relationships between online learning, learning at home and self-management towards Malay Language learning among the students in public universities during $\mathrm{MCO}$

and;

2) To develop a predictive model in the relationships between online learning, learning at home and self-management towards Malay Language learning among the students in public universities during $\mathrm{MCO}$

The hypotheses for the research are:

H1 : There is a significant relationship between online learning and Malay Language learning during MCO

$\mathrm{H} 2$ : There is a significant relationship between learning at home and Malay Language learning during MCO

H3 : There is a significant relationship between self-management and Malay Language learning during MCO

\subsection{Literature Review}

There are 1.5 billion students from over 165 countries who are out of school due to the COVID-19 pandemic as announced by UNESCO on $26^{\text {th }}$ March 2020. Malaysia is one of the 165 countries which have closed all schools and universities due to the pandemic. At the time of writing, there is a second wave of pandemic that forces the government to close all the schools and universities in the red zone areas. There is still a possibility that the Movement Control Order (MCO) is extended after $25^{\text {th }}$ October 2020 due to the increasing number of cases especially in Klang Valley. The COVID-19 pandemic has shown a huge gap in the digital divide among our students.

This paper focuses on the impact of the pandemic on the Malay language students' experience on online education platforms. Due to the pandemic outbreak, there is very limited research in this area. The researcher has therefore surfed through and reviewed current papers, primarily focusing on the transition from the conventional teaching method framework to the online educational method. The review is a study of past literature on 
students' experience on the impact factors. According to the seriousness and urgency of the outbreak of COVID-19 at the end of 2019, the suspension of schools and universities is one of the most common ways to avoid and monitor pandemics.

However, the suspension of lectures has an effect on the success of the courses, but the resumption of lectures will lead to a second spread of the pandemic in universities. Especially during the severe pandemic phase, the best way to solve the mismatch between both the two is to shift from the traditional classroom practices to online classes, which can effectively prevent crowd gathering. The online mode of learning under COVID-19 will also become an important method of preventing and managing the pandemic and ensuring the teaching progress going smoothly. An empirical study by M.Ali \& Fitri (2020), on flipped teaching with the call media in the EFL writing course among the language teachers in Indonesia shows that the activities motivate the students to undergo the teaching and learning process in a different way. The learning environment forces the students to use a technology as a tool and the results show a significant relationship with all the variables.

Researchers like Rodriguez-segura \& Zamora-antuñano (2020) pointed out that the factors that affect user experience were the driving factors that triggered user satisfaction and dissatisfaction. Moreover, students' satisfaction depends on students' needs, expectations, and their existing experiences. Among the Malay language students, a study by Nur Izzah \& Siti Nazleen (2020) showed that the learners' use of their mobile phones to engage with their tasks in writing a thesis had successfully helped the language students to follow their Gantt chart accordingly. This situation gives an overview that online learning can really influence positively the Malay Language learning among the students.

Current research on students' experience and satisfaction over the platforms is conducted through questionnaire surveys or online reviews to obtain basic data, so as to complete the statistical analysis or natural language processing. Fox example, Chen et al. (2020) conducted the research with regard to the impact of the COVID-19 pandemic on user experience with online education platforms. The research was conducted in China. Next, Ain Umaira et al. (2020) mainly focused on the impacts and action taken by the government of Malaysia in adapting to the new health crisis, pandemic Covid-19 in the educational setting. Therefore, the study by Rosmaria et. al (2018), showed that learning at home with full support of their parents can help the students to achieve good academic results. This is in line with the current situation when all the Malay Language students need to stay at home and do the learning process through the online platform during the pandemic.

Current research on online education platforms has mainly focused on the satisfaction evaluation results, willingness for continuous use, and learning influencing factors. Researchers like (Sundarasen et al. 2020) made the conclusion that there is a psychological impact of COVID-19 when the lockdown happened since March 2020. It was further delayed until October 2020. The implications include the new norms of shifting from the conventional way of teaching to online learning. They are also introducing some new policies to the stakeholders like MOE and universities itself as a form of preparation when the urgency happens from time to time. This issue showing that self-management among the students is 
important to make sure that the students are not stressed, that they are effectively prepared for the online classes regularly and without avoiding their own responsibility when staying at home with their family. A study by Baharudin, et. al. (2016) proved that good self-management can improve the Malay Language learning among the students effectively. The study was conducted among the foreign students who take Malay Language as a narrative language when they study in Malaysia. Meanwhile, a study by Di, Zailani \& Ismail (2020) found that self-management among the language students shows a significant relationship with the academic outcomes. The study involved 317 local university students who took a Malay language course, and it indicates that Malay Language learning and educational practices were suited with online learning in their faculties.

In order to give better effect, the priority should be given to the provision of a network environment that students can adapt to. Researcher Yee (2020) found that the continuance intention depends on the type of technology. Wan (2020) verified that users' continuance intention is determined by satisfaction, which in turn is jointly determined by perceived usefulness, information quality, confirmation, service quality, system quality, ease of use and cognitive absorption. Next, a report from Unicef (2020) found that learners' autonomy played an important role in learning through the empirical study of MOOC. There are the following factors that need to be placed into consideration like perceived usefulness, flexibility, reliability, active participation, instructor's response time and consultation.

Lastly, Ji et al. (2020) provided an overview of the five degrees of communication in education: oral gestural, writing, audio, audiovisual and interactive, highlighting the changes brought by the online scenario in the education process, focusing on the character of the student, the teacher and the relationship between them. A lot of the above research focuses on platform satisfaction or curriculum setting, without reviewing and examining the teaching content that combines with the platform of technology. However, in this article, there is still a proportional gain for the foundation of an online educational platform. Few people evaluate the level of online education platforms from the perspective of students' experience, and they do not consider COVID-19 and the possible impact of the outbreak. Based on this, the researcher expects to realize the evaluation of Malay language students' experience during the outbreak of COVID-19 from their perspective on using online learning as a platform in continuing their courses.

\section{Method}

\subsection{Research Participants}

Determination of the study's sample size is done when the population size is determined. The minimum number of subjects for a study is acceptable according to the study design (Chua, 2016). According to Creswell, (2012); and Fraenkel et al., (2015) the total minimum sample size for the descriptive study was 100 people. This study also uses AMOS software through the Structured Equation Model (SEM) for the purpose of data analysis. Therefore, the total sample size should also be balanced according to the method of analysis conducted (Chua, 2016). Hair et al., (2010), suggested that the total sample size for SEM analysis is 100 to 150 people. According to Kline (2011) the most suitable total sample size is 200 respondents. 
Based on the SEM analysis requirement, to determine the sample size, researchers used the sample size calculation method according to the Cochran formula, (1977). This method was chosen because the data obtained is continuous data type with 10 Likert Scale. Finally, with a population of 3500 students in Malay Language Course at 5 selected universities, about 279 students were chosen as the sample size of the study. The universities involved were UPM, UM, UIA, UPSI and UKM. By using a stratified random sampling, the data was collected from all the students. All questions and answers were in Malay language.

\subsection{Instruments}

The instruments have been adapted from Habibah et.al (2020) "Student Learning and Wellbeing During Coronavirus Outbreak Survey". The instruments include 5 sections, section A: Demographic (10 items), section B: Impact of online learning towards Malay language learning (10 items), section C: Learning at home (10 items), section D: Online Learning (5 items) and section E: Self-management during MCO (10 items). It consists of 45 items including the demographic items. All the items had used the 10-Likert scale. The instruments have been tested for reliability and validity before the field study has been conducted. The reliability is defined as the extent to which a measuring device is consistent. Besides, a measurement is deemed reliable or consistent when similar results can be replicated in similar circumstances. To establish the reliability of the analysis of this study, the Cronbach Alpha value of $\leq 0.70$ is considered to be unreliable, while more than $\geq 0.70$ indicates that it is highly acceptable. The reliability analyses for this research were presented in Table 1.

Table 1. Reliability Analysis of Construct

\begin{tabular}{lcc}
\hline Constructs & Number of Items & Alpha Cronbach \\
\hline Malay Language Learning & 10 & 0.889 \\
Online Learning & 5 & 0.878 \\
Learning at Home & 10 & 0.872 \\
Self-management during MCO & 10 & 0.781 \\
\hline
\end{tabular}

All the dimensions achieved the high acceptable value when alpha Cronbach value $>0.70$. They are the dimension of Malay language learning $=0.889$, dimension of online learning $=0.878$, dimension of learning at home $=0.872$ and dimension self-management $=0.781$. Therefore, this instrument achieved the reliability and validity to measure all the variables in this research. All the data has been analyzed with IBM SPSS and AMOS version 25.0.

\subsection{Research Design}

Study design is a basic description of how the process of data collection and data analysis is done by researchers (Noraini, 2013). This study uses the descriptive study design and correlation to explain the relationship and interaction between the variables studied (Fraenkel, Wallen, \& Hyun, 2015). According to Hua (2016), descriptive study is a systematic method adopted to obtain data from the population to understand a current situation involving one or more variables. Meanwhile, correlation design is used based on the advantages of correlation studies, namely making predictions. According to Kline (2011) the purpose of the correlation study is to determine the relationship or make a prediction of the relationship between the 
variables. This study is conducted to identify the relationship between online learning, learning at home and self-management during MCO towards Malay Language learning. Therefore, the quantitative method of survey was used by using a questionnaire through the google form.

\section{Results}

The data were analyzed using the descriptive analysis for demographic items, correlation and regression analysis by the method of the structural equation modelling to test the hypotheses. The respondents' demographics was analyzed to have an overview of the respondents. Next, to answer objective 1, the correlational study was applied to test the assumption of whether or not there is a statistical relationship between the variables. The regression analysis was carried out through SEM, Amos to establish the predictive model in order to be able to answer the objective that has been set.

Table 2. Descriptive Analysis for Respondents Demographic

\begin{tabular}{|c|c|c|}
\hline Details & $\begin{array}{l}\text { Frequency } \\
\qquad(f)\end{array}$ & $\begin{array}{l}\text { Percentage } \\
(\%)\end{array}$ \\
\hline $\begin{array}{c}\text { Gender: } \\
\text { Male } \\
\text { Female }\end{array}$ & $\begin{array}{c}56 \\
223\end{array}$ & $\begin{array}{l}20.2 \\
79.8\end{array}$ \\
\hline $\begin{array}{l}\text { Race: } \\
\text { Malay } \\
\text { Chinese } \\
\text { Indian } \\
\text { Others }\end{array}$ & $\begin{array}{c}240 \\
5 \\
5 \\
27\end{array}$ & $\begin{array}{c}86.6 \\
1.8 \\
1.8 \\
9.7\end{array}$ \\
\hline $\begin{array}{l}\text { Age: } \\
\begin{array}{l}19 \text { Years Old } \\
20 \text { to } 23 \text { Years Old } \\
24 \text { Years Old above }\end{array}\end{array}$ & $\begin{array}{c}0 \\
100 \\
0 \\
\end{array}$ & $\begin{array}{l}0.0 \\
100 \\
0.0\end{array}$ \\
\hline $\begin{array}{l}\text { Courses: } \\
\text { Bachelor of Educational Malay Language }\end{array}$ & 100 & 100 \\
\hline $\begin{array}{c}\text { Universities" } \\
\text { UPM } \\
\text { UIA } \\
\text { UM } \\
\text { UPSI } \\
\text { UKM }\end{array}$ & $\begin{array}{l}60 \\
60 \\
54 \\
55 \\
50\end{array}$ & $\begin{array}{l}21.5 \\
21.5 \\
19.3 \\
19.7 \\
17.9\end{array}$ \\
\hline $\begin{array}{l}\text { Types of Gadget Used through Online Learning: } \\
\text { Laptop Computer } \\
\text { Tablet computer (e.g. iPad, Samsung Galaxy) } \\
\text { Printer } \\
\text { Do not have any gadgets }\end{array}$ & $\begin{array}{c}156 \\
74 \\
44 \\
5\end{array}$ & $\begin{array}{c}55.0 \\
33.9 \\
10.0 \\
1.1\end{array}$ \\
\hline Types of Mobile Used: & & \\
\hline
\end{tabular}




\begin{tabular}{|l|c|c|}
\hline Android & 194 & 69.3 \\
Smartphone (i-phone) & 85 & 30.7 \\
\hline Quality of Internet Connection: & & \\
Strongly dissatisfied & 19 & 6.9 \\
Dissatisfied & 45 & 16.2 \\
Neutral & 143 & 50.9 \\
Satisfied & 63 & 22.7 \\
Strongly Satisfied & 9 & 3.2 \\
\hline Where do you stay during MCO? & 254 & \\
Hometown & 25 & 91.00 \\
Campus & & 9.0 \\
\hline Who you stay with during MCO? & 236 & 84.5 \\
Parents & 25 & 9.0 \\
Friends & 15 & 5.4 \\
Siblings & 3 & 1.1 \\
Grandfather \& grandmother & & \\
\hline
\end{tabular}

An overview of the respondents' profile in Table 2 reveals that the sample is dominated by female students, $n=223$ (79.8\%). A vast majority of the respondents are Malay $(n=240$, 86.6\%), followed by others (Iban, Melanau, Melayu Asli, Kadazan, n=27, 9.7\%), Chinese $(\mathrm{n}=5,1.8 \%)$ and Indian $(\mathrm{n}=5,1.8 \%)$. The age of the respondents ranges from 20 to 23 years old from the Bachelor of Educational Malay language program. All the respondents are from UPM, UIA, UM, UKM and UPSI.

With respect to the gadgets that they used using $\mathrm{MCO}$, either at home or campus, respondents mostly own a laptop computer $(n=156,55 \%)$, use the tablet computer $(n=74,33.9 \%)$ and have their own printer $(n=44,10 \%)$. Unfortunately, there are 5 respondents $(1.1 \%)$ who did not have any gadgets to help them learn throughout the period of MCO. In terms of mobile phone, almost $100 \%$ have a mobile phone, which is android $(n=194,69.3 \%)$ and smartphone $(\mathrm{n}=85,30.7 \%)$.

The respondents stated that $50.9 \%$ of them neutrally agree that their data or internet connection was good during MCO. The remaining had agreed $(\mathrm{n}=71,25.9 \%)$. The rest strongly dissatisfied $(n-19,6.9 \%)$ and dissatisfied $(n=45,16.2 \%)$ that the internet connection was good during MCO. This situation was in line with their place of living during MCO, where almost $91 \%(n=254)$ students were staying at their hometown and only $9 \%(n=25)$ still remained in campus. Some of the respondents are from Sabah and Sarawak where we knew the internet connection will pose some major problems for the students. The respondents for this study are staying with their parents $(n=236,84.5 \%)$, friends $(n=25,9 \%)$, siblings $(\mathrm{n}=15,5.4 \%)$ and grandparents $(\mathrm{n}=3,1.1 \%)$ and this living condition will tend to affect their self-management in adapting to the new norm when it comes to learning online.

Objective 1: To identify the relationships between online learning, learning at home and self-management towards Malay Language learning among the students in public universities during $\mathrm{MCO}$ 


\section{Ml Macrothink}

International Journal of Human Resource Studies

ISSN 2162-3058

2021, Vol. 11, No. 4S

The Pearson Correlation analysis shows that there is a significant relationship with some variables that have been measured. The finding is shown in Table 3.

Table 3. Pearson Correlation for Online Learning, Learning at Home, Self-Management and Malay Language Learning

\begin{tabular}{|l|c|c|c|c|}
\hline & 1 & 2 & 3 & 4 \\
\hline Online Learning & 1 & & & \\
\hline Learning at Home & $0.106^{\mathrm{ns}}$ & 1 & & \\
\hline Self-Management during MCO & $0.431^{* * *}$ & $0.232^{* * *}$ & 1 & \\
\hline Malay Language Learning & $0.578^{* * *}$ & $0.026^{\mathrm{ns}}$ & $0.368^{* * *}$ & 1 \\
\hline
\end{tabular}

$\mathrm{N}=279, * * *$ significant, $\mathrm{ns}=$ not significant

Based on Table 3, the correlation analysis demonstrates that there was a significant relationship between online learning and Malay Language Learning ( $r=0.578, p=0.000)$. The direction of the relationship for both variables was positive, which means that online learning during MCO had a direct impact with the Malay Language learning during MCO among the students. This gives the perception that online learning can be implemented to continue the teaching and learning process as an effective medium to transfer the knowledge. Next, there is no relationship between learning at home with Malay Language learning during MCO $(r=0.026, p=0.294)$. The results mean that there are no impacts in the aspect of learning at home with the learning process during MCO. Lastly, there is a positive and significant relationship between self- management $(r=0.368, \mathrm{p}=0.000)$ among the students and Malay Language learning during MCO. A positive relationship is shown between both variables which indicates that when the students can self-manage during MCO at home, they can also eventually adapt to a new norm in learning Malay Language through the online medium. These results had supported the hypotheses testing for $\mathrm{H} 1, \mathrm{H} 2$ andH3.

Objective 2: To develop a predictive model in the relationships between online learning, learning at home and self-management towards Malay Language learning among the students in public universities during $\mathrm{MCO}$

The Structural Equation Modeling (SEM) analysis was done to produce a predictive model for the relationship between online learning, learning at home and self-management towards Malay Language learning among the students in public universities during MCO. This analysis has shown a good compatibility value to verify the predictive model, which has been built. Results of the SEM analysis show the compatibility value as follows; RMSEA=.061, $\mathrm{IFI}=.937, \mathrm{CFI}=.936, \mathrm{TLI}=.925$ and Chisq/df=2.001 (Figure 1). 


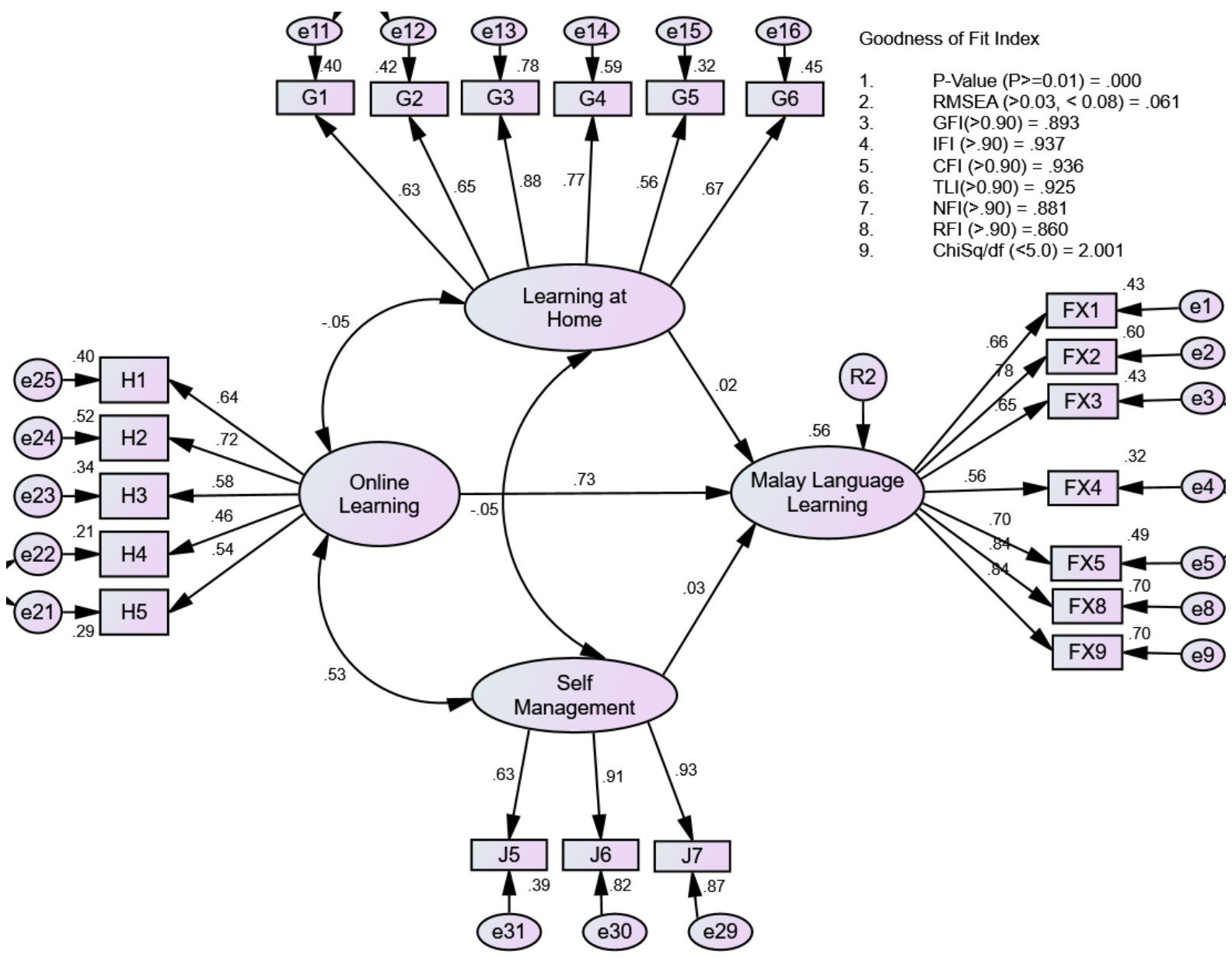

Figure 2. Structural Model

Based on the results of the SEM analysis in Figure 2, good compatibility value was achieved for goodness of fit indices. The coefficient path between online learning and Malay language learning shows a significant relationship $(\beta=0.73, p=0.000)$. Nonetheless, the coefficient path for learning at home $(\beta=0.02, p=0.692)$ and self-management during $\operatorname{MCO}(\beta=0.03, p=0.700)$ were not significant. The results show that both variables are not influenced Malay language learning during MCO. There is only one factor which is the fact that online learning as a new medium in teaching and learning during MCO had contributed to the increase in Malay language learning among the students. About $56 \%$ of the variance value had been contributed by this factor and the remaining $44 \%$ of the variance were possibly contributed by other factors that have not been measured in this research. The estimates for the regression weights are shown in Table 4.

Table 4. Results for Regression Weights

\begin{tabular}{|c|c|c|c|c|c|c|c|}
\hline \multicolumn{3}{|l|}{ Variables } & Estimate & S.E. & C.R. & $\mathrm{P}$ & Results \\
\hline $\begin{array}{l}\text { Malay Language } \\
\text { Learning }\end{array}$ & $<---$ & $\begin{array}{l}\text { Learning } \\
\text { Home }\end{array}$ & .019 & .047 & .396 & .692 & $\begin{array}{c}\text { Not } \\
\text { Significant }\end{array}$ \\
\hline $\begin{array}{l}\text { Malay Language } \\
\text { Learning }\end{array}$ & $<---$ & $\begin{array}{l}\text { Online } \\
\text { Learning }\end{array}$ & .694 & .110 & 6.289 & $* * *$ & Significant \\
\hline
\end{tabular}




\begin{tabular}{|l|l|l|l|l|l|l|l|}
\hline $\begin{array}{l}\text { Malay Language } \\
\text { Learning }\end{array}$ & $<---$ & $\begin{array}{l}\text { Self-manageme } \\
\text { nt }\end{array}$ & .023 & .061 & .385 & .700 & $\begin{array}{c}\text { Not } \\
\text { Significant }\end{array}$ \\
\hline
\end{tabular}

\section{Discussion}

The language learning process is a must for students to ensure the continuity of teaching and learning even during MCO. This study examines the impacts of online learning as a new medium to learn among university students in Malaysia during the COVID-19 pandemic and the lockdown period between April and May 2020. Based on the findings, 56\% of online learning factor contributed to Malay Language learning during MCO. Meanwhile, the remaining $44 \%$ contributed to other factors that have not been measured in this research. Other factors which are learning at home and self-management during $\mathrm{MCO}$ were not giving impacts to students learning, even though there is a significant relationship between those variables.

Based on the demographic info, most of the respondents were shown to have been staying at home $(84.5 \%)$ and together with their parents. In line with the findings from Rosmaria et.al (2018), staying with parents and getting their support, will ensure students' higher achievement in their academic field. Unfortunately, based on the findings in this research, there is no significant relationship between Malay Language learning and learning at home. There are other factors that influence this. One of the reasons is, Malay Language especially in areas like Malay Literature and planning for "drama setting", needs face to face practices. They need to be in campus and meet up to practice. Long distance learning like online learning cannot help them to improve the Malay language learning during this time of pandemic.

Next, research from Chen et al. (2020) showed that the students experienced minimal to moderate, marked to severe, and most extreme anxiety levels, respectively when they studied alone. Findings showed that self-management has a significant relationship with Malay Language learning. Self-management includes for example how the students can handle the stress, how are they together with a family, their responsibility as a son or daughter at home and how they manage themselves when it comes to attending their online classes. Even though the students were staying at home, they were able to manage themselves in their Malay Language learning. A study by Di, Zailani \& Ismail (2020) supported this finding when the empirical study shows the same results. When students can manage themselves accordingly in any situation, or when they can practice by themselves, the continuous learning can happen.

Based on the feedback given by the students in the survey (refers to Figure 1), the most commonly highlighted in online learning was "the students were to make sure that the learning process through online learning could occur smoothly", (item $\mathrm{H} 2$, online learning dimension). Additionally, they were using laptops and smartphones (item H1) as tools to finish their tasks in the course of Malay Language given by the lecturers. Most of the respondents have gadgets for example laptop, printer and tablet computer to help them to complete the tasks. However, $1 \%$ of the students did not have any gadget to use and this will distract their ability to finish the task on the time given. This finding was in line with 
Rodriguez-segura \& Zamora-antuñano, (2020) when they found that an online education platform should consider the teaching environment which directly affects the user experience on the platform: whether the platform can provide students with valuable learning information or guidance to solve their problems in learning; and whether it can guide students to reasonably use the platform and related learning tools. Also, researchers Wargadinata et al., (2020) found that a good response from the students in Indonesia is indicative of a new, effective method in the learning process. The pedagogical approach by lecturers using a technology, forces the students to accept the new movement (M.Ali \& Fitri (2020).

Most of the respondents did agree that they were using a platform by sharing a video through Youtube, Discovery Education, Quizlet and One Course (item H3) to get the information when they need to do the task given by some lecturers. Also, they always communicated with friends to share the information by using Skype, Zoom, Hangout Meet and Lark (item H5). Unfortunately, the major problem that the students have to face is the poor Internet connection. Most of the respondent, or $25 \%$ stated that their internet speed was good, so it allows them to use the online learning effectively. The rest, or $75 \%$ stated that they had moderate and poor internet connection so that did not support them to use online learning as a good platform to learn during MCO. Research by Sundarasen et al., (2020) found that the students faced uphill tasks in terms of technological infrastructure, mainly owing to poor Internet connection. It is also appalling to note that some students attended 6-8 hours of daily online classes using their mobile phones, which further contributed to insurmountable stress not to mention, health issues (Basilaia \& Kvavadze, 2020).

In terms of communication with the lecturers, most of them are using live streaming to do the teaching and learning during MCO (item H4). The students were concerned with their ability to manage the learning process through online learning even though they were staying far from campus. The findings were in line with the research by Nur Izzah \& Siti Nazleen (2020) when they also found that online learning is a useful tool to help Malay Language students in their studies. The commitment was fully given to ensure that their course could continue and all the tasks given will be completed on time. In line with the research from Wargadinata, Maimunah, Febriani, et al., (2020), the overwhelming expectations from their instructors, with multiple assignments and no flexible deadlines, have added to the students' concern about the online learning. Uncertainty regarding their exams, the completion of their semester and graduation, and the need to juggle household chores and take care of siblings while concurrently attending online classes had a huge impact on Malay language learning. The demographic data show that most of them were staying at home with parents (85\%). This situation plus the online learning session with the lecturers, would give an impact on how they could manage themselves. However, the research findings, do not show any influence between self-management with Malay language learning during MCO (Refer Figure 2). Despite this, findings from Agung et al., (2020) show that students were distressed because they were helpless in their plans to launch their progress in learning and to finish their studies.

Further research is proposed for the inclusion of successful strategies in terms of teaching and learning in Malay Language course used by the students during emergency times such as the 
COVID-19 pandemic. Students should really be guided towards teaching, learning and assessment methods in the "norm today", that could have the dual benefit of maximizing student performance and diminishing factors such as lacking the internet access and detrimental emotional impacts on learning, especially in the Malay language course, which seem to require more face-to- face lessons among students.

Meanwhile, the COVID-19 pandemic has developed a continuous pattern of social distancing beyond the immediate pandemic, causing loss of emotional support and wider societal impacts. Malay language course, for example, also involves learning about a poem or drama so students need to have direct engagement and face-to- face learning in order to get a better understanding about the learning objectives. Developing and sustaining relationships amongst students and instructors are fundamental to successful learning, which is one of the key characteristics in student life. Students need to value the performance in order to achieve successful results in Malay language learning.

In order to learn online via these platforms, a student would need to have access to the platform. In terms of access, the prerequisite to learn via the online platform would be to have Internet and a device such as a computer, laptop, tablet or smartphone. In urban areas, there are still complaints that students have to share the devices and they could not fully utilize the lessons online due to slow internet connections or simply due to the fact there are not enough devices to share. However, in rural and remote areas such as the Orang Asli villages in Peninsular, Sabah and Sarawak, the coverage of the internet is downright limited. Some villages do not even have access to electricity, or the use of electricity is limited to night time use only.

\section{Conclusion}

Through this research, the researcher hopes to make up for the literature on the differences of online education platforms in case of emergencies, so as to improve the education focusing on Malay language learning from various perspectives. This paper collected data among the Malay Language students using the online education platforms during the outbreak of COVID-19. The study found that during COVID-19, the Malay language course students use the platforms to share information and communicate with their lecturers. Findings show that there has been a significant relationship between online learning and Malay language learning during MCO. Different concerns and requirements, and some similar problems with other research for example poor internet connection need to be dealt with. The results also show that there are no impacts of learning at home and self-management during the outbreak of the pandemic. There are several suggestions, which include improving the support service by providing comprehensive, timely, convenient and fast support services for learners conducive to the maintenance of learners' positive learning attitude especially in learning language.

\section{Acknowledgments}

The researchers would like to thank the Putra Research Grant Research, University Putra Malaysia, for funding this research (GP-956400). 


\section{References}

Agung, A. S. N., Surtikanti, M. W., \& Quinones, C. A. (2020). Students' Perception of Online Learning during COVID-19 Pandemic: A Case Study on the English Students of STKIP Pamane Talino. Soshum: Jurnal Sosial Dan Humaniora, 10(2), 225-235.

Ain Umaira, M. S., Syafiqah Nur, A. S., Rathhedevi, T., Nor Kamariah, N., Azmawani, A. R., Zamberi, S., Aini, I., \& Mohamed Thariq, H. S. (2020). International Journal of Infectious Diseases COVID-19 outbreak in Malaysia: Actions taken by the Malaysian government. International Journal of Infectious Diseases, 97, 108-116. https://doi.org/10.1016/j.ijid.2020.05.093

Baharudin, A., Mazlina, S., Ikhsan, M., \& Siti. A.B (2016). The Interesting Teaching and Learning of Malay Language to Foreign Speakers: Language through Cultures. DINAMIKA ILMU. 16. 1. 10.21093/di.v16i1.295.

Basilaia, G., \& Kvavadze, D. (2020). Transition to online education in schools during a SARS-CoV-2 coronavirus (COVID-19) pandemic in Georgia. Pedagogical Research, 5(4), $1-9$.

Chen, T., Peng, L., Jing, B., Wu, C., \& Yang, J. (2020). The Impact of the COVID-19 Pandemic on User Experience with Online Education Platforms in China. Sustainability, 12(7329), 1-31.

Chua, Y. P. (2016). Mastering Research Methods. (pp. 86-89). Penerbit Universiti Malaya.

Cochran, W. F. (1977). Sampling techniques. (3rd Edition). United States of America: Harvard University.

Creswell, J. W. (2012). Planning, Conducting and Evaluating Quantittaive and Qualittaive Research. Educational Research: Planning, Conducting, and Evaluating Quantitative and Qualitative Research (4th Edition). Nebraska, New York: Pearson Inc.

Di, X., Zailani, M., \& Ismail, W. (2020). Self-Regulated Learning Strategies As Academic Self-Management Skills In Malaysian Public Universities. MOJEM: Malaysian Online Journal Of Educational Management, 8(3), 64-81. Retrieved from https://mojem.um.edu.my/article/view/24710

Ferdig, R. E., Baumgartner, E., Hartshorne, R., Kaplan-Rakowski, R., \& Mouza, C. (2020). Teaching, technology, and teacher education during the covid-19 pandemic: Stories from the field. Waynesville, NC, USA: Association for the Advancement of Computing in Education $(A A C E)$.

Fraenkel, J. R, Wallen, N. E., \& Hyun, H. H. (2015). How to Design and Evaluate Research in Education (9th Edition). New York: Mc Graw Hill Inc.

Habibah., AB.J., Ismail., A.R., Ismi Arif,. I., Steven., E.K., Mohd Shahir.,S.O (2020). Student Learning and Wellbeing During Coronavirus Outbreak. Innovate University Putra Malaysia.

Hair, Black, W. C., Babin, B. J., \& Anderson, R. E. (2010). Multivariate Data Analysis (7th 
Edition). San Francisco: Pearson Prentice Hall Inc.

Hua, A. K. (2016). Pengenalan Rangkakerja Metodologi dalam Kajian Penyelidikan: Satu Kajian Kes. Journal of Social Sciences and Humanities, 1(May), 17-23. http://doi.org/10.6084.

Ji, T., Liu, Z., Wang, G., Guo, X., \& Akbar, S. (2020). Detection of COVID-19: A Review of The current Literature and Future Perspectives. Biosensors and Bioelctronics, 112455(January).

Kline, R. B. (2011). Principles and Practice of Structural Equation Modelling (Edition 3). New York: Guilford Press.

M. Ali.,G \& Fitri.,N (2020). Flipped Teaching with CALL Media in EFL Writing Course: Indonesian EFL. Writing Teachers' Reflection. Pertanika Journal of Social Sciences \& Humanities Vol. 28 (S2)

National CPRC, Ministry Of Health Malaysia (2020). "Jumlah Kes dan Kematian Terkini Covid-19 Malaysia pada 25 Mac 2020”. Retrieved from National CPRC, Ministry Of Health Malaysia on 17 October 2020.

Nur Izzah., O. \& Siti Nazleen., A.R (2020). Adult Learners' Perceptions on Acquiring Communicative Malay Language Proficiency as a Foreign or Second Language and Attitude towards Mobile Learning: A Preliminary Study. Pertanika Journal of Social Sciences \& Humanities Vol. 28 (S2)

Noraini Idris. (2013). Penyelidikan Dalam Pendidikan (2nd Edition). Kuala Lumpur: MCGraw Hill Education (Malaysia) Sdn. Bhd.

Rinta, H. (2020, April 1). Equity in distance learning and inclusion measures. Retrieved from UNESCO Institute for Lifelong Learning:

Rodriguez-segura, L., \& Zamora-antuñano, M. A. (2020). Teaching Challenges in COVID-19 Scenery: Teams Platform-Based Student Satisfaction Approach. Sustainability, 12(7514), $1-29$.

Rosmaria Omar, Nor Aniza Ahmad, Siti Aishah Hassan \& Samsilah Roslan (2018). Importance Of Teachers' Competency Through Students' Perspection In Relationships Between Parental Involvement And Motivation With Students' Achievement. Jurnal Sains Humanika. Penerbit UTM.

Sundarasen, S., Chinna, K., Kamaludin, K., \& Nurunnabi, M. (2020). Psychological Impact of COVID-19 and Lockdown among University Students in Malaysia: Implications and Policy Recommendations. International Journal of Environmental Research and Public Health, 17(6206).

Unicef. (2020). COVID - 19 A Child rights Crisis (Issue 1).

UNESCO. (2020, April 8). UNESCO COVID-19 Response. Retrieved from https://en.unesco.org/covid19 
Wan, Y. S. (2020). Education during COVID-19 (Issue April).

Wargadinata, W., Maimunah, I., Eva, D., \& Rofiq, Z. (2020). Student's responses on learning in the early COVID-19 pandemic. Tadris: Journal of Education and Teacher Training, 5(1), $141-153$.

Wargadinata, W., Maimunah, I., Febriani, S. R., \& Humaira, L. (2020). Mediated Arabic Language Learning for Higher Education in COVID-19 Situation. Izdihar: Journal of Arabic Language Teaching, Linguistics, and Literature, 3(1), 59-78.

Wang, Y. (2020, April 1). The Practices of Chengdu. Retrieved from UNESCO Institute for Lifelong Learning: https://uil.unesco.org/system/files/chengdu_presentation_0401.pdf

Winthrop, R. (2020). COVID-19 and school closures: What can countries learn from past emergencies? Retrieved from https://www.brookings.edu/research/covid-19-and-school-closures-what-can-countries-learnfrom-past-emergencies/

Woolley, S., Sattiraju, N., \& Moritz, S. (2020, March 26). U.S. Schools Trying to Teach Online Highlight a Digital Divide. Retrieved from https://www.bloomberg.com/news/articles/2020-03-26/covid-19-school-closuresreveal-disparity-in-access-to-internet

Yee, C. P. (2020). COVID-19: Impact On The Tertiary Education Sector in Malaysia (Issue May).

\section{Appendix}

Table A1. Reliability Analysis of Construct

\begin{tabular}{lcc}
\hline Constructs & Number of Items & Alpha Cronbach \\
\hline Malay Language Learning & 10 & 0.889 \\
Online Learning & 5 & 0.878 \\
Learning at Home & 10 & 0.872 \\
Self-management during MCO & 10 & 0.781 \\
\hline
\end{tabular}

Table A2. Descriptive Analysis for Respondents Demographic

\begin{tabular}{|l|c|c|}
\hline Details & $\begin{array}{c}\text { Frequency } \\
(f)\end{array}$ & $\begin{array}{c}\text { Percentage } \\
(\%)\end{array}$ \\
\hline Gender: & 56 & 20.2 \\
Male & 223 & 79.8 \\
Female & & \\
\hline Race: & 240 & 86.6 \\
Malay & 5 & 1.8 \\
Chinese & 5 & 1.8 \\
Indian & 27 & 9.7 \\
Others & & \\
\hline Age: & & \\
\hline
\end{tabular}




\begin{tabular}{|l|c|c|}
\hline 19 Years Old & 0 & 0.0 \\
20 to 23 Years Old & 100 & 100 \\
24 Years Old above & 0 & 0.0 \\
\hline Courses: & & \\
Bachelor of Educational Malay Language & 100 & 100 \\
\hline Universities" & & \\
UPM & 60 & 21.5 \\
UIA & 60 & 21.5 \\
UM & 54 & 19.3 \\
UPSI & 55 & 19.7 \\
UKM & 50 & 17.9 \\
\hline Types of Gadget Used through Online Learning: & & \\
Laptop Computer & 156 & 55.0 \\
Tablet computer (e.g. iPad, Samsung Galaxy) & 74 & 33.9 \\
Printer & 44 & 10.0 \\
Do not have any gadgets & 5 & 1.1 \\
\hline Types of Mobile Used: & & \\
Android & 194 & 69.3 \\
Smartphone (i-phone) & 85 & 30.7 \\
\hline Quality of Internet Connection: & & \\
Strongly dissatisfied & 19 & 6.9 \\
Dissatisfied & 45 & 16.2 \\
Neutral & 143 & 50.9 \\
Satisfied & 63 & 22.7 \\
Strongly Satisfied & 9 & 3.2 \\
\hline Where do you stay during MCO? & 254 & 9.0 \\
Hometown & 25 & 1.1 \\
Campus & & \\
\hline Who you stay with during MCO? & 36.5 \\
Parents & & \\
Friends & & \\
Siblings & & \\
Grandfather \& grandmother & & \\
\hline
\end{tabular}

Table A3. Pearson Correlation for Online Learning, Learning at Home, Self-Management and Malay Language Learning

\begin{tabular}{|l|c|c|c|c|}
\hline & 1 & 2 & 3 & 4 \\
\hline Online Learning & 1 & & & \\
\hline Learning at Home & $0.106^{\mathrm{ns}}$ & 1 & & \\
\hline Self-Management during MCO & $0.431^{* * *}$ & $0.232^{* * *}$ & 1 & \\
\hline Malay Language Learning & $0.578^{* * *}$ & $0.026^{\mathrm{ns}}$ & $0.368^{* * *}$ & 1 \\
\hline
\end{tabular}


$\mathrm{N}=279, * * *$ significant, $\mathrm{ns}=$ not significant

Table A4. Results for Regression Weights

\begin{tabular}{|c|c|c|c|c|c|c|c|}
\hline Variables & & & Estimate & S.E. & C.R. & $\mathrm{P}$ & Results \\
\hline $\begin{array}{l}\text { Malay Language } \\
\text { Learning } \\
\text { Malay Language } \\
\text { Learning }\end{array}$ & $<--$ & $\begin{array}{l}\text { Learning } \\
\text { Home } \\
\text { Online } \\
\text { Learning }\end{array}$ & .019 & .047 & 6.289 & .692 & $\begin{array}{l}\quad \text { Not } \\
\text { Significant } \\
\text { Significant }\end{array}$ \\
\hline $\begin{array}{l}\text { Malay Language } \\
\text { Learning }\end{array}$ & $<---$ & $\begin{array}{l}\text { Self-manageme } \\
\text { nt }\end{array}$ & .023 & .061 & .385 & .700 & $\begin{array}{c}\text { Not } \\
\text { Significant }\end{array}$ \\
\hline
\end{tabular}

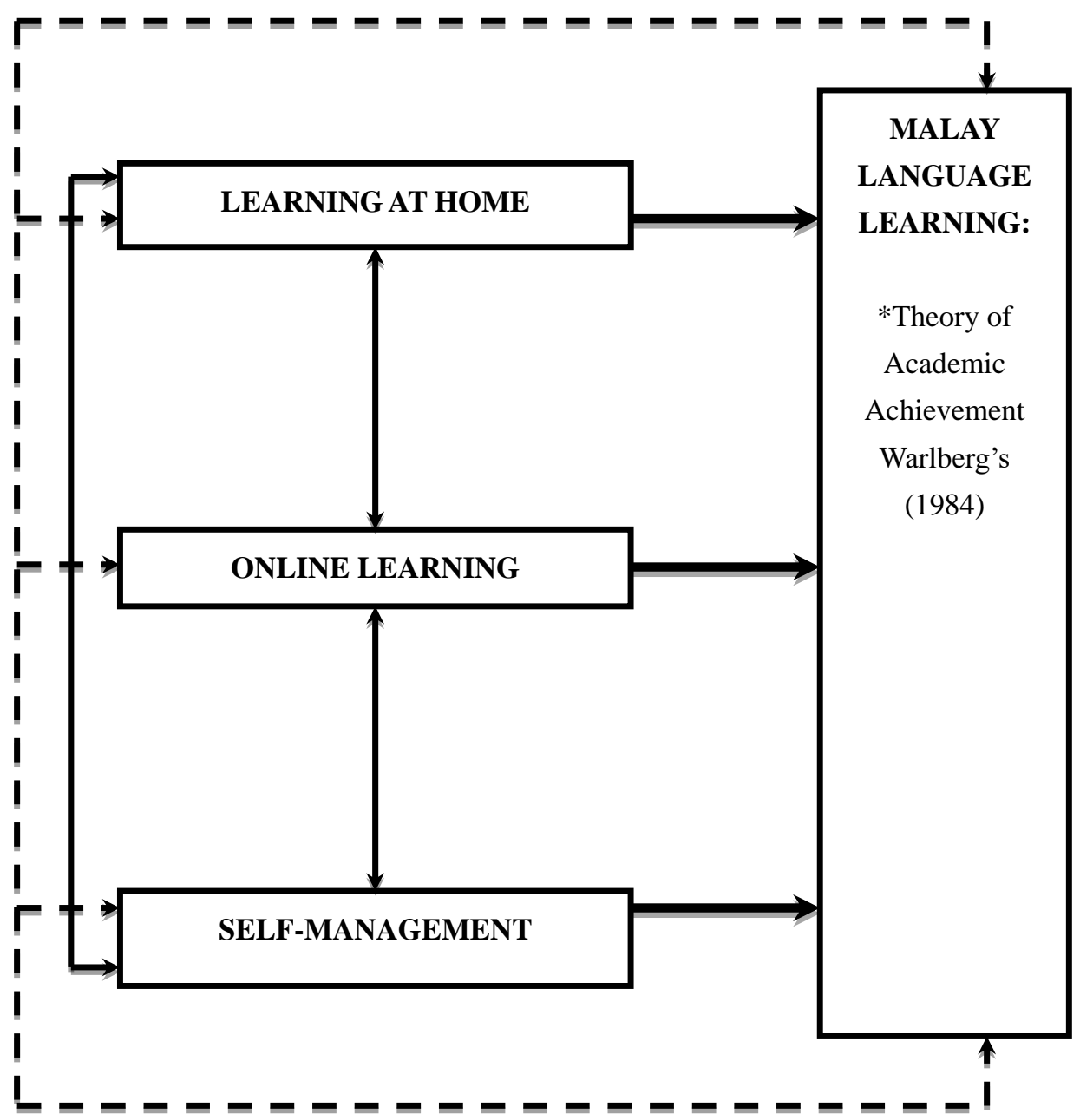

Figure B1. Conceptual Framework 


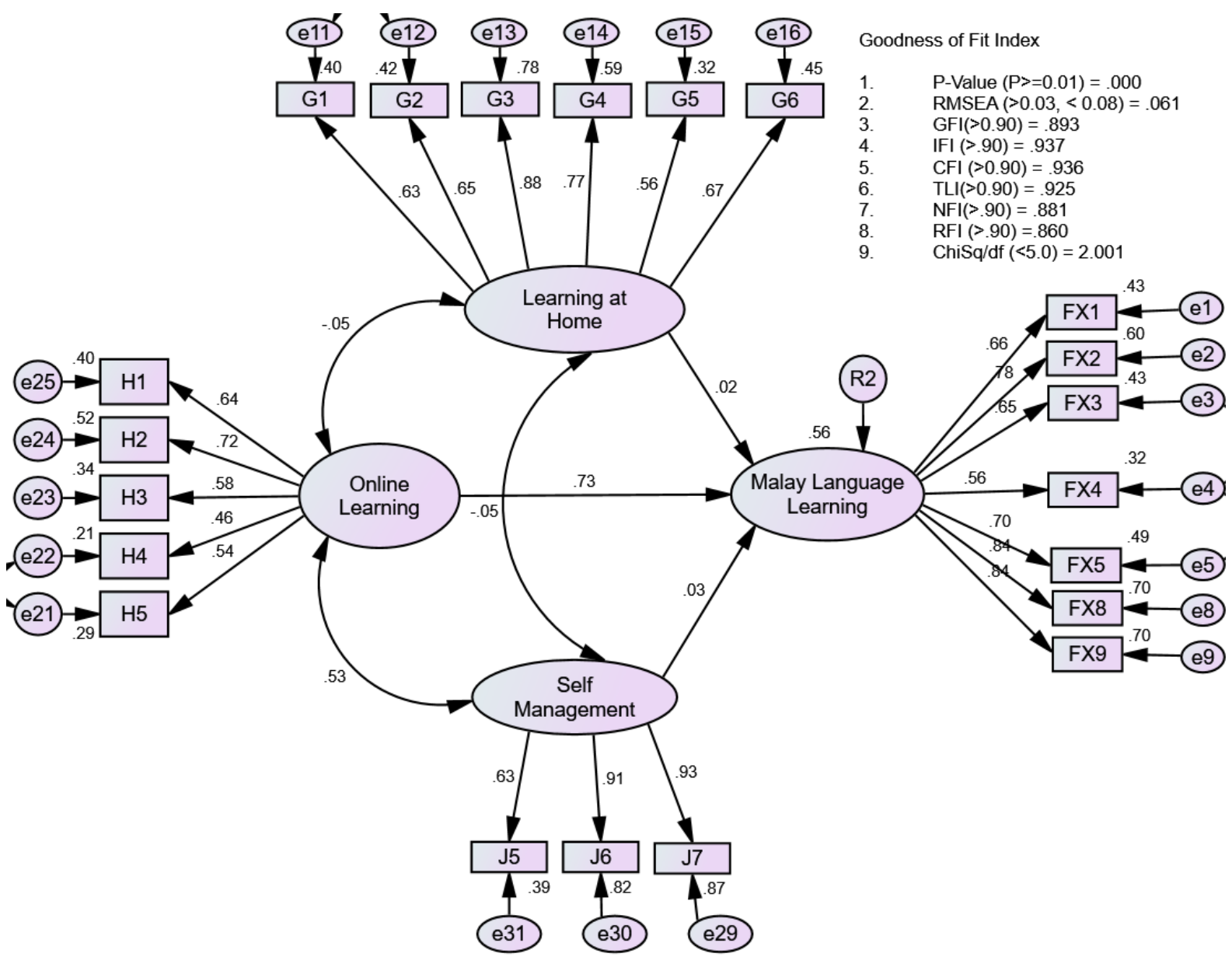

Figure B2. Structural Model

\section{Copyright Disclaimer}

Copyright for this article is retained by the author(s), with first publication rights granted to the journal.

This is an open-access article distributed under the terms and conditions of the Creative Commons Attribution license (http://creativecommons.org/licenses/by/4.0/). 